\title{
Study of the Behavior Pattern, Carbon Reduction Effect and Business Costs of Electric Motorcycles on Island
}

\author{
Shyang-Chyuan Fang*
}
*Department of Tourism and Leisure, National Penghu University of Science and Technology.No.300, Liuhe Rd., Magong City, Penghu County 880, Taiwan

E-mail addresses: chyuansf@gms.npu.edu.tw.

\begin{abstract}
Global warming and climate change have led to extreme changes in climatic conditions in recent years. The Taiwan government designates the construction of the Kinmen County as low carbon islands, to promote the operation of 100 electric motorcycles and battery demonstration. This study combined with island tourism, after boarding the island, visitors can rent electric motorcycles from the passenger service center and coordinate with the island tour map to show the location of the battery exchange points, so as to facilitate the search. During the operation, the amount of electric motorcycle lease is 15,551 times, the total mileage of motor vehicle is $284,404 \mathrm{~km}$, the number of battery exchange is 622 times, the lease income is about NT\$900,000. To reduce carbon and economic benefits of the assessment, compared to the motorcycles (50 c.c), electric motorcycles (EM 100) can reduce the carbon emissions by $8,726 \mathrm{~kg}$, reducing energy costs of NT\$422,594.
\end{abstract}

Keywords: low carbon island; electric motorcycles; green transport; battery exchange; carbon emissions

\section{Introduction}

Global warming and climate change have led to extreme changes in climatic conditions in recent years. In addition, as a result of the rapid increase in human activities, fossil fuels are rapidly depleted. As a result, carbon reduction has become a daunting challenge for the 21st century. Many countries have actively 
implemented measures to combat local greenhouse gas emissions [1-2]. Fifth Assessment Report (AR5) of the Intergovernmental Panel on Climate Change (IPCC) stressed that unless mitigation actions were implemented, the global average surface temperature would rise by $3.7-4.8^{\circ} \mathrm{C}$ in 2100 [3]. Therefore, actively promoting green policies, creating employment opportunities for sustainable investment, implementing environmental and ecological sustainability, and building a Low-carbon society with a low-carbon economy should be a key issue for countries around the world. As a result, many countries around the world have taken action to calculate their greenhouse gas (GHG) emissions using specific technologies [4], which has been translated into concrete action.

Many urban residents, especially in Asia, have adopted motorcycles as the main vehicle for urban transport. Relatively high but dispersed population and work density, narrow streets and a uniform distribution of road networks make motorcycling a convenient choice for many urban point-to-point trips. Low-cost Chinese motorcycles, credit and cheap fuel also make it an affordable option. Motorcycles can not only use space effectively because of their size and maneuverability [5-7], but their efficiency may increase the proportion of traffic including motorcycles [8]. According to statistics published by the Taiwan Environmental Protection Agency, the number of carbon monoxide, hydrocarbons and particulate matter produced by traditional motorcycles accounted for $27 \%, 48 \%$ and $23 \%$ of the total amount generated by all road vehicles. Motorcycles have become the main source of air pollution in Taiwan. In order to achieve the objectives of the Convention on Sustainable Energy policy, the Government has implemented carbon emission controls in the transport sector, and has developed allowable energy performance standards and air pollution emission standards for motorcycles [9]. In addition, the Government has introduced a number of measures to promote electric motorcycles. These include exemption from the consumption tax and fuel duty of motorcycles, and price subsidies for purchasers.

Personal mobility has a number of harmful effects on the environment due 
to the prevailing use of fossil fuels. Spreading ownership and the use of electric motorcycles is widely considered as a symptom of unsustainable transport [10]. Motor vehicle use is seen as a major contributor to climate change, air pollution [11] and oil dependence [12]. In order to mitigate the negative effects of personal transport, electrification (e-mobility) is proposed and increasingly being adopted by governments worldwide. The purpose of most electrification policies is to improve local pollution levels and to tackle climate change by tapping into renewable power sources [13]. Global motor vehicle ownership exceeds 1.7 billion units [14], but less than $0.2 \%$ of the global light duty vehicle fleet are electrically powered [15]. A large proportion of electric motorcycles are privately owned, so the adoption of electric vehicles (EV) relies heavily on consumers' perception of them [16]. Consequently, it is important to understand the consumers' motives in using EV's, in order to successfully promote or market them.

\subsection{Powered two-wheeler aberration}

Historically, motor vehicle ownership has been closely related to per-capita income, but the relationship is non-linear. The highest growth rates are historically observed when annual income levels range from 3,000-10,000 US\$. Europe and Japan already had a few individuals at this income level by the 1960s, but highly populated, developing countries in Asia currently have many individuals in this mid-income range [17] (Dargay et al., 2007).

This historic observation may not hold in Asia. Taiwan has an economic ranking that is similar to Germany's, in terms of GDP per capita (PPP) [18]. The 10,000 USD income level was surpassed during the 2000s. While car ownership did increase, Taiwan still has the highest ratio of PTW per capita in the world. Many households own both cars and motorcycles and use them for different types of trips. A similar development can be expected in other South-East-Asian countries, such as Vietnam, Indonesia or Thailand. These have a similar climate, high population density and are home to much of the global motorcycle fleet. Law et al. [19] noted that, "there is always a time lag between economic growth 
and the motorcycle to passenger car ownership ratio". However, the substitution of motorcycle ownership to car ownership has been found to be statistically insignificant. Wen et al. [20] noted that motorcycles are preferable for short-range transport, even for car owners. This study also found that household income is not significantly associated with motorcycle ownership and that moderate increases in the price of gasoline trigger a shift from car to motorcycle usage. From a lifecycle perspective, electric motorcycles have the potential to reduce energy consumption and harmful emissions [21]. However, the lack of rider protection at high speeds remains a major issue and much research has been focused on safety [22-23]. The contribution to (or rather the obstruction of) traffic flow and the way in which PTW's affect road capacity and traffic performance is problematic [24]. There are pros and cons to the use of electric motorcycles for future mobility, but the increasing growth cannot be ignored, and is a motivation for this study.

Under the current research background, the increase of energy generation cost and the market price rise constitute the main barriers for consumers to adopt green energy [25]. Although opinion polls show consumers are willing to pay a premium for green energy [26-27], Green energy company's market share is still very low [28]. The cost of green energy is higher than conventional power, which discourages many potential consumers [25]. The future success of green energy depends on effective branding and marketing communication strategies that can improve consumer perceptions [29-30].

Although technical features and green electric marks provide consumers with utilitarian benefits, the purchase of green products may have psychological benefits. With the improvement of living standard, people pay more and more attention to the sustainability of the environment. An environment-friendly utilization and production system should be established. Green use behavior is influenced by many factors. The willingness of consumers and the ability to engage in green use are critical [31]. Diffusion of green use is a huge challenge. More and more literatures show that the government should play a central role in promoting green utilization [32-39]. 
In Taiwan, the government is pushing for carbon-reduction efforts and is expected to push 6 low-carbon cities and complete 4 low-carbon life cycles in 2020. Designate the construction of Kinmen and Penghu county as low carbon islands. Kinmen is located on the mainland of the Fujian southeast Xiamen Bay, three sides of the mainland around the west from Xiamen output 10 nautical miles, east across the Taiwan Strait and 150 nautical miles apart. This study contributes to the consumer preference of electric motorcycles in three main ways. First, it adds an additional and substantial difference in the location of the case. In the existing studies in Asia, Vietnam, China and Taiwan, Kinmen is smaller and has a higher share of motorcycle models than any other city. This size and relative dependence on motorcycles makes it a better case for small and medium scale fast-growing motorcycle cities. Second, the survey provides an electric alternative to the fee infrastructure based on the tourism environment. This contrasts with most of the schemes proposed in the current study of consumer preferences for high-power electric motorcycles [40-41]. While fast-charging and battery swaps may make electric vehicles more appealing, these charging systems require expensive infrastructure investments that may take years to achieve. Third, the survey includes more questions about consumer preferences for electric motorcycles and concerns about the local and global environment. The data provide an estimate of how much environmental-conscious respondents are willing to put on a motorcycle.

This paper is structured as follows: Section 2 describes the methodology, including the scope of research and objective. Section 3 presents results, Section 4 explains the results. Section 5 concludes the results and discusses their policy implications for the suggestion

\section{Methodology}

\subsection{Scope of research}

In order to better understand the complex nature of powered two-wheelers (PTW) [42], a typology for electric motorcycles (EM) is proposed. This study combined with island tourism, after boarding the island, visitors can rent electric motorcycles from the passenger service center (electric motorcycle leasing station) 
and coordinate with the island Tour map to show the location of the roundabout, the locations of the spots, the location of the battery exchange points and the road rescue and emergency contact telephone information, so as to facilitate the search. Through the collection of relevant data to understand the behavior patterns of tourists and the amount of pollution reduction.

\subsection{Objective}

The objective of this study was followed

(1) Create a Low-carbon life circle, implement carbon reduction, the low-carbon concept in daily life.

(2) Reduce energy consumption and reduce carbon dioxide emissions.

(3) Constructed with the best use of motor vehicle environment, providing the best business model.

\section{Results}

3.1. Set electric motorcycles battery exchange station

The Terminal passenger Service Centre (S1) provides battery Exchange services, the choice of other battery exchange locations is to provide tourist convenience as the primary consideration, after space analysis, selected tourist attractions near, respectively, in Warrior Fort (S2), Lake well Head (S3), General Temple (S4), Rijo Temple (S5) and the city center 7-11 convenience Stores (S6). A total of 5, providing battery Exchange services, of which S6 is a 24-hour battery Exchange station, giving visitors the most convenient service. The relative position of the battery Exchange station settings is shown in Figure 1. 


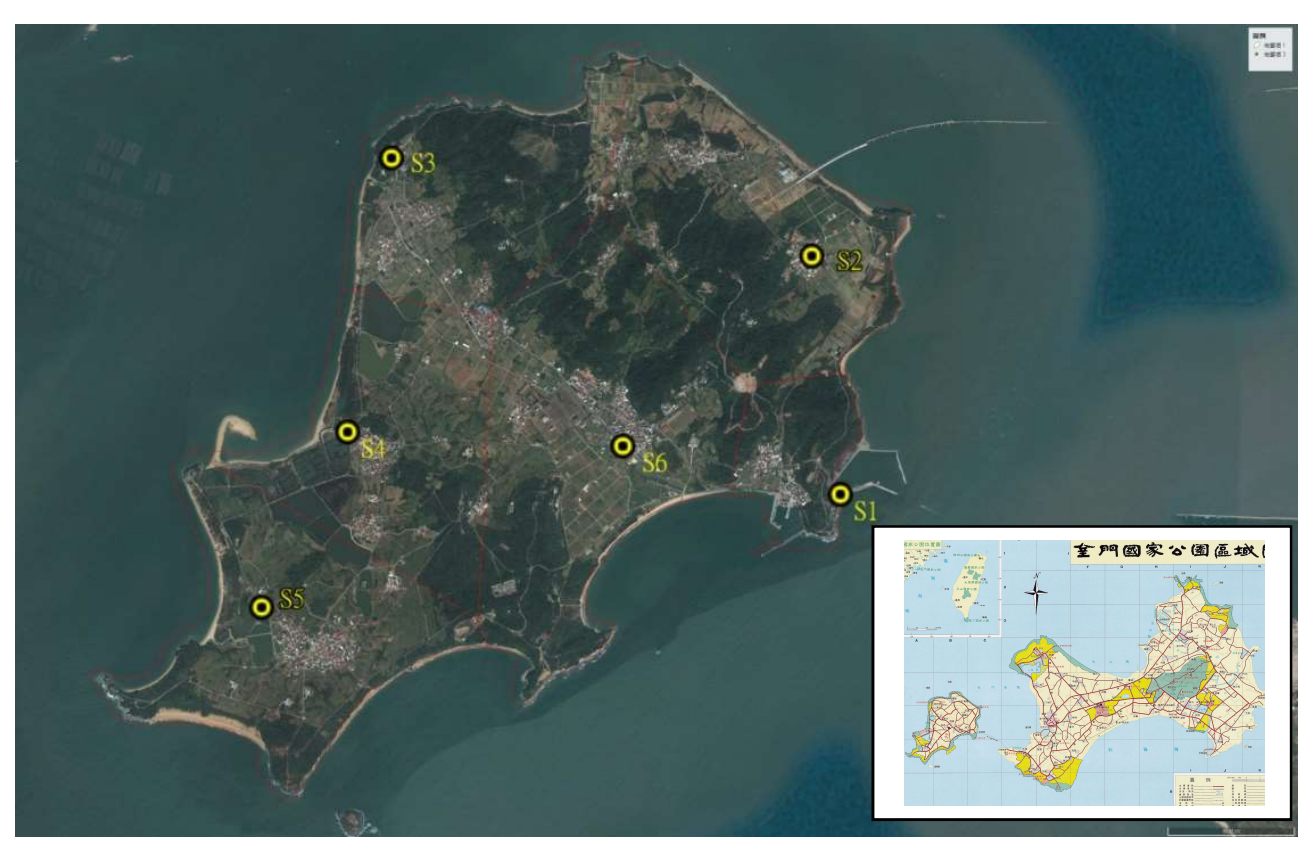

Figure 1. Battery exchange station location

\subsection{Electric motorcycles and battery usage}

In 2017, planners handled electric motorcycle tours, recording daily electric motorcycle rentals and battery exchange operations, and electric motorcycle maintenance records (including battery wear). The results show that the total number of electric motorcycle leased in the operation period is 15,551 , from January to December, respectively leasing 1,057 trips, 1,077 trips, 1,510 trips, 1,455 trips, 1,412 trips, 1,256 trips, 1,442 trips, 1,210 trips, 1,056 train, 1,243 train, 1,430 train and 1,394 trips, according to the data, the promotion period due to leasing concessions, and is a tourist season, in addition to the beginning (JanuaryFebruary) during the promotion period, leasing trips are showing positive growth trend (shown in Figure 2). 


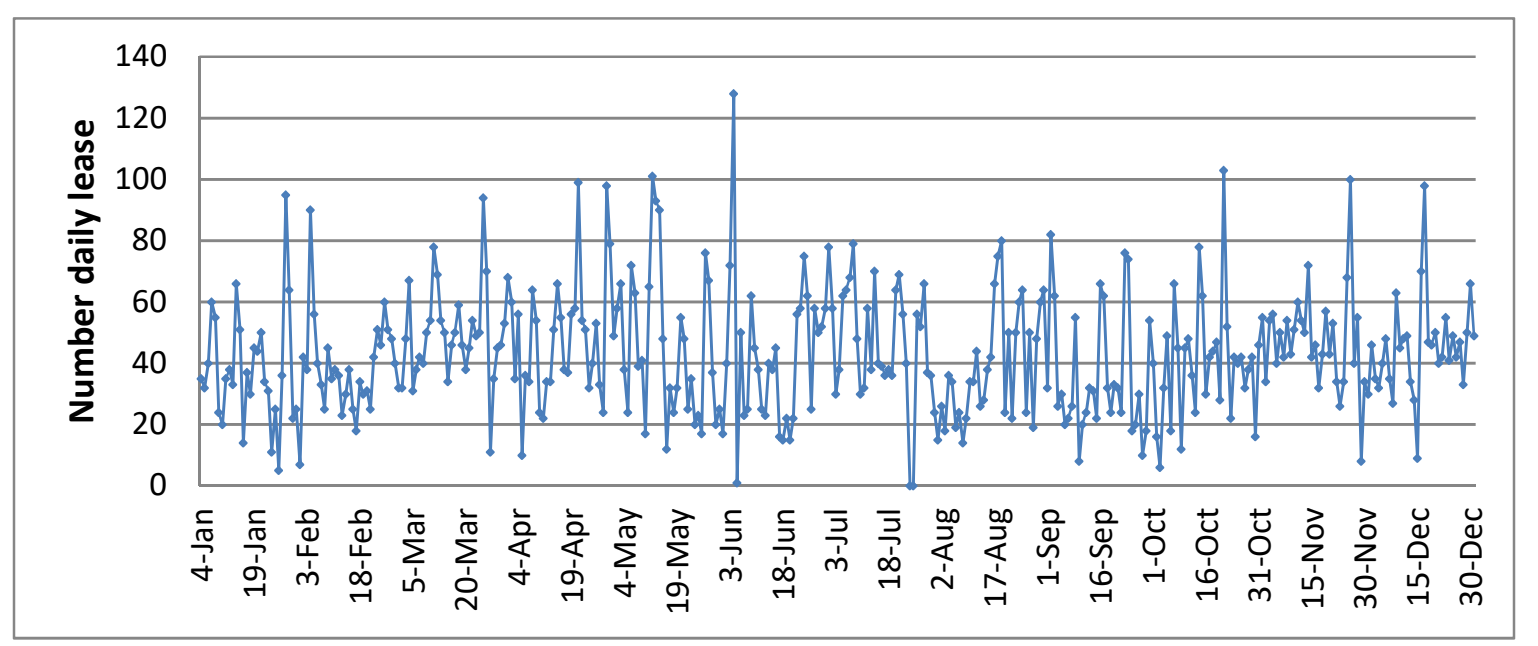

Figure 2. Daily lease count of electric motorcycles

At the same time, the analysis of non-holiday and holiday lease electric motorcycles, showing the January non-holiday period (Monday to Friday) the average daily lease electric motorcycles for 25 trips, holidays (Saturday, Sunday) Average daily lease electric motorcycles for 59; February non-holiday period (Monday to Friday) The average daily lease electric motorcycles for the 28 train, Holiday (Saturday, Sunday) Average daily lease electric motorcycles for 55 trips; March non-holiday period (Monday to Friday) Average daily lease electric motorcycles for 30 trips, holidays (Saturday, Sundays) Average daily lease electric motorcycles for 53 trips respectively; During the April non-holiday period (Monday to Friday), the average daily lease electric motorcycles for 35 trips, holidays (Saturday, Sunday) Average daily lease electric motorcycles for 68 trips; May non-holiday period (Monday to Friday) Average daily lease electric motorcycles for 34 trips, holidays (Saturday, Sundays) The average daily lease electric motorcycles is 73 vehicles respectively; June non-holiday period (Monday to Friday) the average daily lease electric motorcycles for 34 trips, holidays (Saturday, Sunday) Average daily lease electric motorcycles for 67 trips; July nonholiday period (Monday to Friday) Average daily lease electric motorcycles for 36 trips , Holiday (Saturday, Sunday) The average daily lease electric motorcycles is 63 vehicles respectively; August non-holiday period (Monday to Friday) the average daily lease electric motorcycles for 32 trips, Holiday (Saturday, Sunday) Average daily lease electric motorcycles respectively for 53 trips; September non- 
holiday period (Monday to Friday) The average daily lease electric motorcycles for the 22 trips, Holiday (Saturday, Sunday) Average daily lease electric motorcycles for 45 trips; October non-holiday period (Monday to Friday) Average daily rental electric motorcycles for 26 trips, holidays (Saturday, Sundays) Average daily lease electric motorcycles for 69 trips respectively ; During the November non-holiday period (Monday to Friday), the average daily lease electric motorcycles for 30 trips, holidays (Saturday, Sunday) Average daily lease electric motorcycles for 70 trips; December non-holiday period (Monday to Friday) Average daily lease electric motorcycles for 28 trips, holidays (Saturday, Sundays) The average daily lease electric motorcycles is 65 trips respectively (shown in Figure 3, 4).

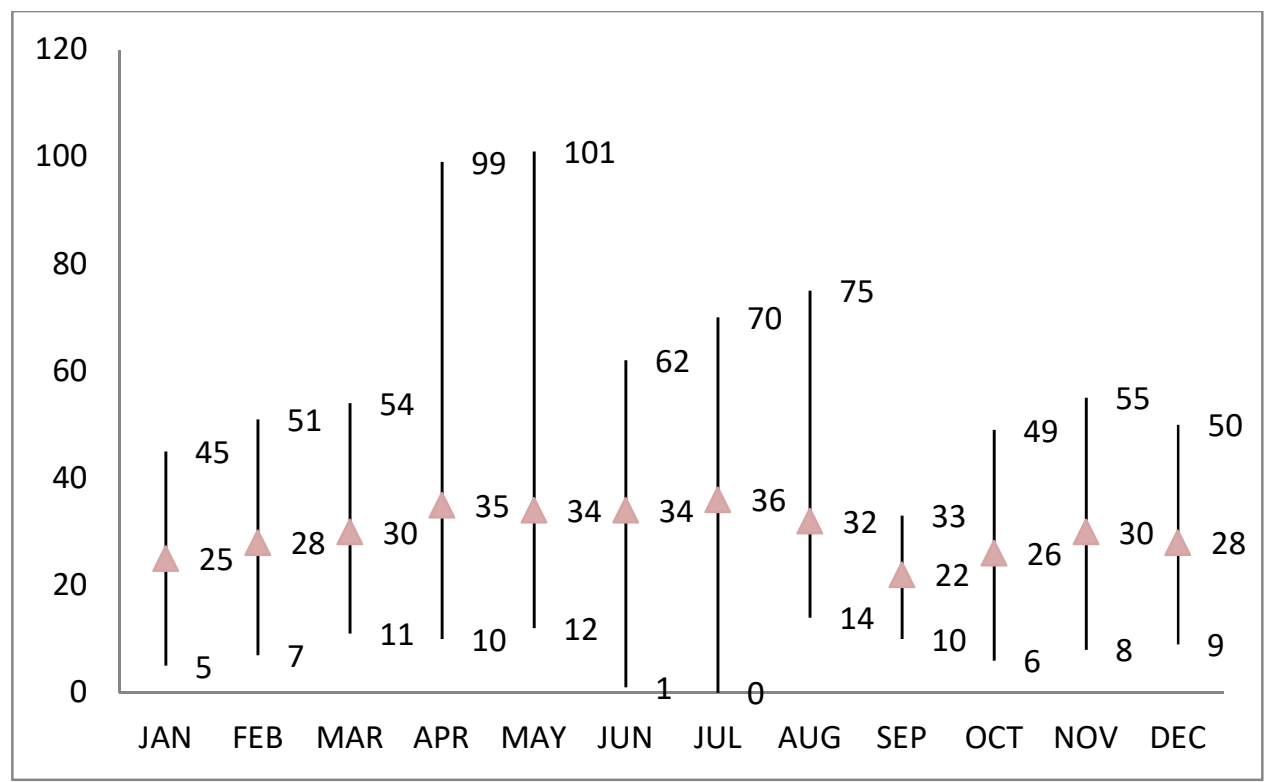

Figure 3. Analysis of leased trips during non-holiday 


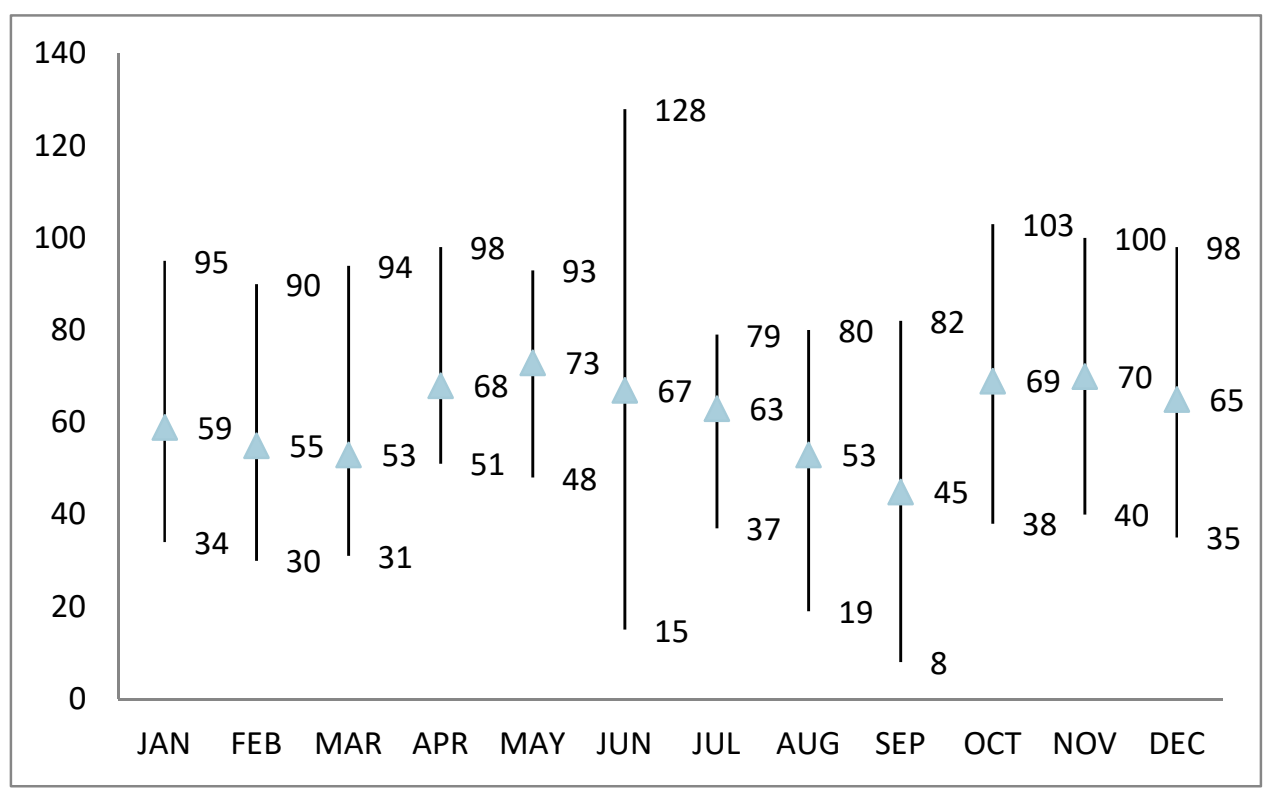

Figure 4. Analysis of leased trips during holidays

Further, statistics of the number of leases for each period of time, as at the end of December, the total operation of 362 days, the number of leases for each period, from 8:00 to 9:00 for 1,220 trips, the average 2.9 trips, holiday average 3.1 trips; 9:00 to 10:00 for 2,782 trips, Non-holiday average 4.0 trips, holiday average of 13.5 trips; 10:00 to 11:00 for 3,254 trips, non-holiday average 5.5 trips, holiday 16.4 average trips, 11 o'clock to 12 o'clock 2,418 trips, non-holiday average 4.6 trips, holiday average 8.2 trips, 12:00 to 13:00 for 1,518 trips, non-holiday average 2.7 trips, holiday average of 5.2 trips; 13:00 to 14:00 for 1,366 trips, non-holiday average 3.0 trips, holiday average 4.8 trips; $14: 00$ to 15:00 for 1,586 trips, Nonholiday average 3.5 trips, holiday average 4.6 trips, 15:00 to 16:00 for 911 trips, non-holiday average of 1.7 trips, holiday average 3.8 trips, 16:00 to 17:00 for 356 trips, not holidays average 0.5 trips, holiday average 1.0 trips, 17:00 to 18:00 for 140 trips, non-holiday average 0.3 trips, holiday average 0.1 trips. According to the data, the number of leases is more than 9:00 to 12:00. The number of leases for each period are detailed in Figure 5 and Table 1, 2. 


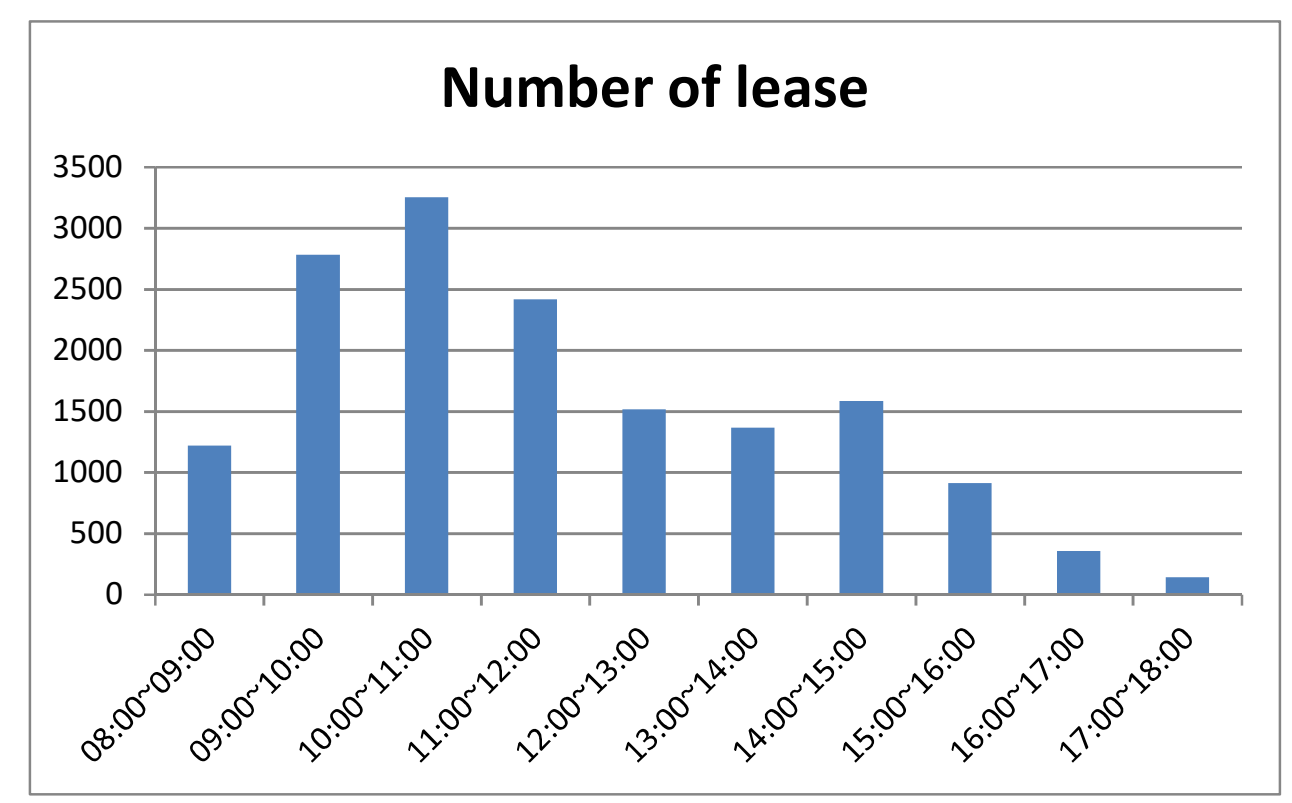

Figure 5. Statistics on the number of leases in each period of a day

Table 1. Average of leased trips during non-holiday periods

\begin{tabular}{ccccccccccc}
\hline $\begin{array}{c}\text { Period } \\
\text { of a day } \\
\text { Month }\end{array}$ & $\mathbf{0 8 \sim 0 9}$ & $\mathbf{0 9 \sim 1 0}$ & $\mathbf{1 0 ~ 1 1}$ & $\mathbf{1 1 ~ 1 2}$ & $\mathbf{1 2 ~ 1 3}$ & $\mathbf{1 3 \sim 1 4}$ & $\mathbf{1 4 ~ 1 5}$ & $\mathbf{1 5 \sim 1 6}$ & $\mathbf{1 6 ~ 1 7}$ & $\mathbf{1 7 \sim 1 8}$ \\
\hline JAN & 3.2 & 3.1 & 3.7 & 2.2 & 1.5 & 3.6 & 3.3 & 1.4 & 0.5 & 0.3 \\
FEB & 3 & 3.0 & 3.4 & 2.8 & 1.6 & 3.5 & 3.2 & 1.4 & 0.4 & 0.5 \\
MAR & 3 & 3.3 & 3.8 & 2.9 & 1.8 & 3.7 & 3.5 & 1.6 & 0.3 & 0.4 \\
APR & 4 & 4.2 & 4.9 & 4.0 & 2.2 & 4.3 & 4.1 & 2.5 & 0.7 & 0.7 \\
MAY & 5 & 4.5 & 5.9 & 4.3 & 2.3 & 4.1 & 4 & 2.2 & 0.6 & 0.6 \\
JUN & 3.4 & 7.9 & 8.1 & 5.4 & 3 & 2.5 & 4 & 1.7 & 0.4 & 0 \\
JUL & 3.1 & 5.4 & 7.8 & 7 & 4.4 & 3 & 2.6 & 1.4 & 0.5 & 0 \\
AUG & 2 & 0.7 & 7.5 & 6 & 2.5 & 2.3 & 3.3 & 2 & 0.5 & 0 \\
SEP & 0.9 & 3.6 & 3.9 & 5 & 2.3 & 1.5 & 3 & 1.6 & 0.9 & 0.1 \\
OCT & 2.4 & 4 & 5.7 & 5 & 3.4 & 2.3 & 3.9 & 1.4 & 0.6 & 0 \\
NOV & 2.6 & 4.3 & 5.6 & 5.5 & 3.8 & 2.6 & 3.7 & 1.9 & 0.5 & 0.3 \\
DEC & 2.5 & 4.4 & 5.8 & 5.2 & 3.9 & 2.1 & 3.2 & 1.3 & 0.6 & 0.5 \\
Average & $\mathbf{2 . 9}$ & $\mathbf{4}$ & $\mathbf{5 . 5}$ & $\mathbf{4 . 6}$ & $\mathbf{2 . 7}$ & $\mathbf{3}$ & $\mathbf{3 . 5}$ & $\mathbf{1 . 7}$ & $\mathbf{0 . 5}$ & $\mathbf{0 . 3}$ \\
\hline
\end{tabular}

Table 2. Average of leased trips during holiday periods

\begin{tabular}{ccccccccccc}
\hline $\begin{array}{c}\text { Period } \\
\text { of a day } \\
\text { Month }\end{array}$ & $\mathbf{0 8 ~ 0 9}$ & $\mathbf{0 9 \sim 1 0}$ & $\mathbf{1 0 \sim 1 1}$ & $\mathbf{1 1 ~ 1 2}$ & $\mathbf{1 2 ~ 1 3}$ & $\mathbf{1 3 ~ 1 4}$ & $\mathbf{1 4 ~ 1 5}$ & $\mathbf{1 5 \sim 1 6}$ & $\mathbf{1 6 ~ 1 7}$ & $\mathbf{1 7 \sim 1 8}$ \\
\hline JAN & 2.4 & 12.5 & 20.0 & 6.2 & 5.3 & 4.9 & 3.4 & 4.0 & 0.8 & 0.1 \\
FEB & 2.1 & 12.1 & 19.5 & 5.0 & 4.2 & 4.8 & 3.0 & 4.3 & 1.1 & 0.1 \\
MAR & 2.3 & 13.1 & 20.2 & 6.0 & 5.0 & 4.7 & 3.2 & 4.1 & 0.9 & 0.2 \\
APR & 2.6 & 16.3 & 21.4 & 7.0 & 5.2 & 5.1 & 3.8 & 4.5 & 0.8 & 0.3 \\
MAY & 3.6 & 16.6 & 22.5 & 7.8 & 6.3 & 5.3 & 4.3 & 5 & 0.9 & 0.4 \\
JUN & 7.6 & 13.8 & 11.6 & 9.2 & 5.9 & 5.8 & 4.7 & 4 & 1.4 & 0.1 \\
JUL & 5.5 & 13.8 & 14.1 & 15.3 & 6.3 & 2.5 & 4.1 & 1.8 & 0.3 & 0 \\
AUG & 3.3 & 8.9 & 14.7 & 5.2 & 3.2 & 6.3 & 5.2 & 3.8 & 1.8 & 0 \\
SEP & 1 & 12.3 & 9.4 & 5 & 5.3 & 3.1 & 4.1 & 2.4 & 0 & 0 \\
OCT & 2.5 & 14.4 & 14.8 & 11 & 5.1 & 5.1 & 6.5 & 4.1 & 1 & 0 \\
NOV & 2.3 & 14.1 & 14.7 & 10 & 5.5 & 5.3 & 6.1 & 3.3 & 1.2 & 0.1 \\
DEC & 2.1 & 13.9 & 14.2 & 10.5 & 5.2 & 5.1 & 6.7 & 4.0 & 1.3 & 0.2 \\
Average & $\mathbf{3 . 1}$ & $\mathbf{1 3 . 5}$ & $\mathbf{1 6 . 4}$ & $\mathbf{8 . 2}$ & $\mathbf{5 . 2}$ & $\mathbf{4 . 8}$ & $\mathbf{4 . 6}$ & $\mathbf{3 . 8}$ & $\mathbf{1}$ & $\mathbf{0 . 1}$ \\
\hline
\end{tabular}


In addition to the battery exchange, the battery exchange station service personnel will be torn off the sticker, paste on the registration form and charge NT\$20 for exchange fees, people at the exchange stations to replace the battery count, as shown in Table 3 and Figure 6,7.

Table 3. Battery Exchange Quantity statistics

\begin{tabular}{|c|c|c|c|c|c|c|}
\hline $\begin{array}{l}\text { Battery exchange station } \\
\text { Month }\end{array}$ & $\mathrm{S} 2$ & S3 & S4 & S5 & S6 & Subtotal \\
\hline JAN & 2 & 4 & 6 & 6 & 12 & 30 \\
\hline FEB & 3 & 5 & 7 & 5 & 14 & 34 \\
\hline MAR & 1 & 3 & 7 & 4 & 13 & 28 \\
\hline APR & 4 & 6 & 10 & 7 & 16 & 43 \\
\hline MAY & 1 & 8 & 9 & 5 & 15 & 38 \\
\hline JUN & 7 & 11 & 13 & 3 & 19 & 53 \\
\hline JUL & 11 & 13 & 19 & 9 & 29 & 81 \\
\hline AUG & 9 & 17 & 16 & 7 & 31 & 80 \\
\hline SEP & 3 & 8 & 11 & 15 & 13 & 50 \\
\hline OCT & 4 & 11 & 18 & 8 & 17 & 58 \\
\hline $\mathrm{NOV}$ & 6 & 13 & 20 & 10 & 19 & 68 \\
\hline DEC & 5 & 12 & 19 & 7 & 16 & 59 \\
\hline Total & 56 & 111 & 155 & 86 & 214 & 622 \\
\hline
\end{tabular}

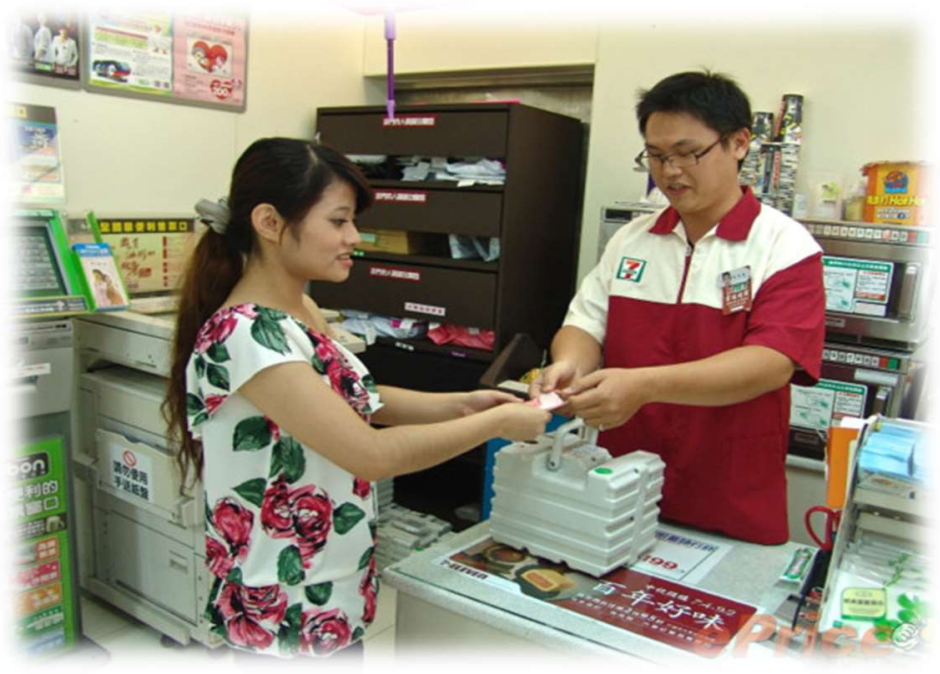

Figure 6. User advanced battery replacement 


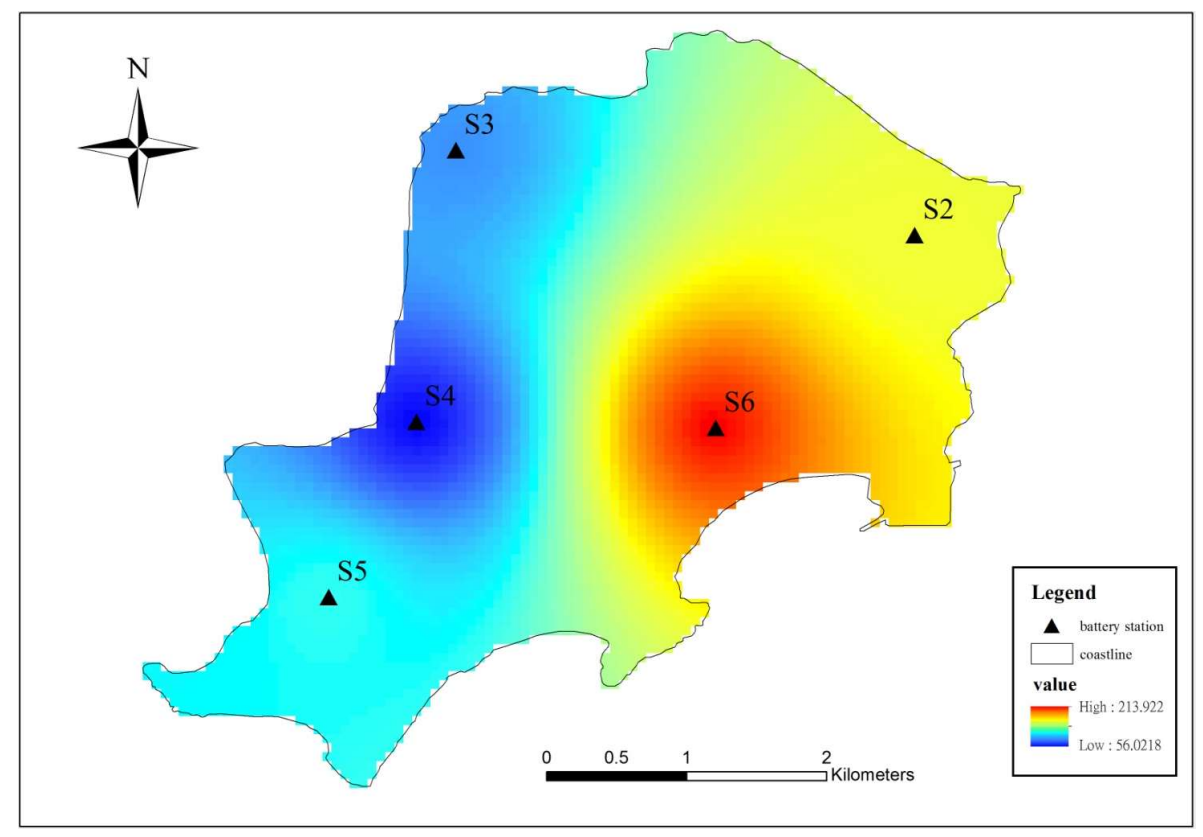

Figure 7. Concentration diagram of battery Exchange quantity of battery exchange station

\section{Results Analysis}

\subsection{Carbon reduction and effectiveness evaluation}

The total mileage of 100 electric motorcycles is $284,404 \mathrm{~km}$, charge and discharge the total number of 11,060 times, charge once for $1 \mathrm{kWh}$, the average electricity can run about $38 \mathrm{~km} / \mathrm{kWh}$. To reduce carbon and economic benefits of the assessment, compared to the motorcycles (50 c.c), electric motorcycles (EM 100) can reduce the carbon emissions by $8,726 \mathrm{~kg}$, reducing energy costs of NT\$422,594. Reductions in carbon and energy costs are detailed in Table 4.

Table 4. Carbon reduction and effectiveness evaluation

\begin{tabular}{|c|c|c|c|c|c|}
\hline \multirow[t]{2}{*}{ Vehicle types ${ }^{(1)}$} & \multicolumn{2}{|c|}{$\begin{array}{c}\text { Emissions per } \\
\text { unit of pollutant } \\
\mathbf{g} / \mathbf{k m} \\
\end{array}$} & \multirow{2}{*}{$\begin{array}{l}\text { Mileage } \\
\text { of driving } \\
(\mathrm{km})\end{array}$} & \multirow[t]{2}{*}{$\begin{array}{l}\text { Carbon emissions } \\
\text { (kg/12months) }\end{array}$} & \multirow[t]{2}{*}{$\begin{array}{c}\text { Cost of energy } \\
\text { (NT\$/12months) }\end{array}$} \\
\hline & $\mathrm{CO}$ & $\mathrm{CO}_{2}$ & & & \\
\hline Motorcycle 50c.c & 3.5 & 57.18 & & CO: 996/CO2: 6,262 & 445,046 \\
\hline $\begin{array}{l}\text { Electric } \\
\text { motorcycle (EM } \\
100)\end{array}$ & - & 30 & 284,404 & 8,532 & 22,452 \\
\hline \multicolumn{4}{|c|}{$\begin{array}{l}\text { Carbon reduction and effectiveness evaluation of } \\
\text { economic benefits }\end{array}$} & $\begin{array}{l}-8,726 \\
(-51 \%)\end{array}$ & $-422,594(-95 \%)$ \\
\hline
\end{tabular}

Note: (1) Assessment of vehicle types: Because of the horsepower relationship with 50c.c fuel vehicles, as electric motorcycles (EM3A6 (extraction 20Ah) 100) comparison basis. (2) Pollutant emission basis: Taiwan EPA website http://ncs.epa.gov.tw/BB/B-02c0.htm (3) carbon emission and energy cost calculation benchmark (fuel vehicle oil consumption: $20 \mathrm{~km} / \mathrm{L}$, reference oil price of NT32 /liter; electric vehicle energy consumption: $38 \mathrm{~km} / \mathrm{kWh}$, reference electricity price is NT\$3 $/ \mathrm{kWh})$ 


\subsection{SWOT analysis}

For the island-driven motor vehicle process, the SWOT analysis, namely Strengths, Weakness, Opportunities and Threats analysis, such as Table 5. Compared with the general fuel motorcycle, the electric motorcycles analyses the opportunity that the influence of the external environment change may bring to the island driving motor vehicle and the challenge it may face. The analysis results show that the internal advantage and external opportunity of the electric motorcycles are the most important because of the government's environmental protection policy. The rise in environmental awareness, zero of pollution and low-noise electric motorcycles are expected, and the use of electric motorcycles to reduce energy consumption and carbon emissions; As for the internal disadvantage and external threat, the electric motorcycles endurance and horsepower are insufficient, the majority of people are still unable to enjoy the popular.

Further comparing the various cost estimates of electric motorcycles and general fuel motorcycles, electric motorcycles in the cost, every three years about more than the general fuel motorcycles savings of more than NT\$10,000, carbon emissions can be reduced by $50 \%$, another according to the Taiwan government announced the annual Table of fixed asset durability, depreciation rate of fixed assets and relevant provisions of income tax law the endurance of the machine bicycle is three years, the price of motor vehicle and the durability of the car, with 3 years as the benchmark estimate, an average of one month the cost of NT $\$ 1,865$.

Cost comparisons and amortization details are shown in table 6, 7.

Table 5. The SWOT analysis of electric motorcycle driving

\begin{tabular}{ll}
\hline \multicolumn{1}{c}{ Strengths } & \multicolumn{1}{c}{ Weakness } \\
\hline $\begin{array}{l}\text { 1. The operating cost is } 1 / 3 \text { of the } \\
\text { motorcycles. }\end{array}$ & $\begin{array}{l}\text { 1. Insufficient horsepower, } \\
\text { unable to meet the pursuit } \\
\text { 2. Rents are cheaper than motorcycles. }\end{array}$ \\
$\begin{array}{ll}\text { 3. Save energy consumption and reduce } \\
\text { carbon emissions. }\end{array}$ & $\begin{array}{l}\text { 2. Cannot be used across the } \\
\text { island. }\end{array}$ \\
$\begin{array}{ll}\text { 4. Low pollution and low noise can help } \\
\text { improve the living quality of residents. }\end{array}$ & $\begin{array}{l}\text { 3. Endurance is inferior to the } \\
\text { motorcycle. }\end{array}$ \\
\hline
\end{tabular}


5. Near the dock, it is advantageous for the tourists to borrow the car.

\begin{tabular}{|c|c|}
\hline Opportunities & Threats \\
\hline 1. Government policy development. & 1. The choice of motorcycle is \\
\hline $\begin{array}{l}\text { 2. The charging station matches the scenic } \\
\text { spot, promotes the quality and the }\end{array}$ & $\begin{array}{l}\text { much more, and the people } \\
\text { are easy to accept. }\end{array}$ \\
\hline $\begin{array}{l}\text { regional sightseeing tour, drives the } \\
\text { attraction profit. }\end{array}$ & $\begin{array}{l}\text { 2. Impact on local car rental } \\
\text { operators and taxi }\end{array}$ \\
\hline $\begin{array}{l}\text { 3. The islands belong to the Closed field, } \\
\text { promote Lohas, slow tour, and help } \\
\text { promote electric motorcycles. }\end{array}$ & operators. \\
\hline
\end{tabular}

Table 6. Cost comparison between electric motorcycle and general fuel motorcycle

\begin{tabular}{|c|c|c|c|c|}
\hline \multirow{2}{*}{\multicolumn{3}{|c|}{ Vehicle types }} & & \\
\hline & & & Light electric motorcycle & Light motorcycle \\
\hline \multicolumn{3}{|l|}{ Price (NT\$) } & $50,000 \sim 70,000$ & $50,000 \sim 60,000$ \\
\hline \multirow{3}{*}{$\begin{array}{l}\text { Amount of } \\
\text { government } \\
\text { subsidy }\end{array}$} & \multicolumn{2}{|c|}{$\begin{array}{l}\text { Central government } \\
\text { (NT\$) }\end{array}$} & 10,000 & 0 \\
\hline & \multicolumn{2}{|c|}{ Taiwan EPA (NT\$) } & $\begin{array}{l}3,000 \\
\text { (Replacement of two-stroke } \\
\text { locomotive for electric } \\
\text { motorcycle) }\end{array}$ & 0 \\
\hline & \multicolumn{2}{|c|}{$\begin{array}{l}\text { Local government } \\
\text { (NT\$) }\end{array}$} & 15,000 & 0 \\
\hline \multicolumn{3}{|c|}{$\begin{array}{l}\text { Actual purchase price (Price -Amount } \\
\text { of government subsidy) (NT\$) }\end{array}$} & $40,000 \sim 50,000$ & $50,000 \sim 60,000$ \\
\hline \multicolumn{3}{|c|}{ Battery cost (NT\$) } & $\begin{array}{l}\text { 15,000 25,000 } \\
\text { (Securing } 30000 \mathrm{~km} \text { or } \\
\text { Securing 3years) }\end{array}$ & 0 \\
\hline \multicolumn{3}{|c|}{ License tax (NT\$) } & 0 & 0 \\
\hline \multicolumn{3}{|c|}{ Fuel tax (per two years) (NT\$) } & 0 & 600 \\
\hline \multicolumn{3}{|c|}{ Energy costs $(\mathrm{NT} \$ / \mathrm{km})^{(1)}(\mathrm{NT} \$)$} & 0.075 & 1.6 \\
\hline \multicolumn{3}{|c|}{$\begin{array}{l}\text { Cumulative energy costs for } 3 \text { years } \\
\text { (Battery replacement fee not } \\
\text { included) }{ }^{(2)}(\mathrm{NT} \$)\end{array}$} & 1,125 & 24,000 \\
\hline \multirow{3}{*}{\multicolumn{2}{|c|}{$\begin{array}{l}\text { Regular maintenance } \\
\text { costs (NT\$) }\end{array}$}} & Engine oil & 0 & 200 (per1000km) \\
\hline & & Gear oil & 80 (per 2000km) & 80 (per 2000km) \\
\hline & & Air filter & 0 & $300($ per $5000 \mathrm{~km})$ \\
\hline \multicolumn{3}{|c|}{$\begin{array}{l}\text { Cumulative maintenance costs for } 3 \\
\text { years (Only the above maintenance } \\
\text { items) }{ }^{(3)}(\mathrm{NT} \$)\end{array}$} & 600 & 4,500 \\
\hline \multicolumn{3}{|c|}{3 Year Depreciation (4) } & 0.536/year & 0.536/year \\
\hline \multicolumn{2}{|c|}{ Pollution amount (5) } & $\mathrm{SOx}(\mathrm{g} / \mathrm{km})$ & 0.0384 & - \\
\hline
\end{tabular}




$\begin{array}{lll}\mathrm{CO}(\mathrm{g} / \mathrm{km}) & 0 & \text { Less than } 3.5 \\ \begin{array}{l}\mathrm{HC}+\mathrm{NOx} \\ (\mathrm{g} / \mathrm{km})\end{array} & 0.0492 & \text { Less than } 2.0 \\ \mathrm{CO} 2(\mathrm{~g} / \mathrm{km}) & 30 & 57.18\end{array}$

\section{Note:}

(1) The electric motorcycles fills about $1 \mathrm{kWh}$ each time, fills one time electricity tariff about NT3, endurance about $40 \mathrm{~km}$; the average fuel motorcycle can run $20 \mathrm{~km} / \mathrm{L}$ (92 unleaded petrol at NT\$32/L).

(2) The average driving distance of $13.6 \mathrm{~km}$ per person, three years about $15,000 \mathrm{~km}$.

(3) The calculation method of the regular maintenance cost is calculated in 15,000 km in 3 years.

(4) According to the government announced the annual Table of fixed assets, fixed assets depreciation rate and income tax regulations. The endurance of the machine bike is three years, and it has depreciated by 0.536 per annum according to the method of decreasing rate.

(5) Implement the emission standard of the new vehicle in the three-phase regulation of locomotive in 1998. Motorcycle cold running, traffic jam, poor maintenance, high pollution, and is a mobile pollution source, prevention and control is not easy, high cost.

Table 7. Electric motorcycle price and durable amortization (NT\$)

\begin{tabular}{cccc}
\hline Service life & 1th year & 2th year & 3th year \\
\hline 1th month & 67,160 & 44,773 & 22,386 \\
2th month & 65,294 & 42,907 & 20,520 \\
3th month & 63,429 & 41,042 & 18,655 \\
4th month & 61,563 & 39,176 & 16,789 \\
5th month & 59,698 & 37,310 & 14,924 \\
6th month & 57,832 & 35,445 & 13,058 \\
7th month & 55,966 & 33,579 & 11,193 \\
8th month & 54,101 & 31,714 & 9,327 \\
9th month & 52,235 & 29,848 & 7,462 \\
10th month & 50,370 & 27,982 & 5,596 \\
11th month & 48,504 & 26,117 & 3,731 \\
12th month & 46,638 & 24,251 & 1,865 \\
\hline
\end{tabular}

Note: Price and durable life (starting from the date the vehicle are manufactured and finished)

Given the design of the survey, it is not clear whether these consumers and at what price or quality level will be willing to consider electric motorcycles. Finally, the existing energy network may be difficult to deal with by increasing the energy demand from high permeable high-powered electric motorcycles. Overnight $100 \%$ for high-power electric motorcycles will require an estimated $63 \%$ of current energy consumption to maintain an average daily travel of $30 \mathrm{~km}$ per motorcycle [43].

Even a modest shift to low performance electric motorcycles can also pose a challenge to energy distribution. The probability of choosing electric 
motorcycles increases with the increase of speed, the endurance, the increase of charging time, the decrease of fuel cost and the decrease of monthly payment. This is intuitive, in line with existing research results, on price, quality and preferred alternative fuel vehicles [44-49].

\subsection{Business Cost Planning}

This study purchased the cost of light electric motorcycles (100) and the original batterys (50 groups) NT\$6,99.6 million, the annual operating costs of NT\$819,500, annual manpower costs NT\$1.32 million, annual depreciation costs NT\$383,100, it is estimated that the total cost of this year is NT\$9.4886 million.

The annual cost of the following year is NT\$2.5226 million, if according to the Table 4.7-3 evaluation method, the current implementation of the 12-month rental revenue costs NT $\$ 800,000$, therefore, the promotion of electric motorcycles need to compile about NT\$1.7 million of the budget to achieve the goal of sustainable operation. The proposed reduction of the budget is as follows: first, to increase the number of rental passengers, the second increases the rental costs. If the cost of NT\$252.26 to the current rental costs of 4 hours each time NT\$150 (not in the home), 365 days, the daily need to rent at least 47 vehicles. Rental costs can be adjusted up to NT\$450/day, such as weekdays cost 80 percent, local residents dozen 60 percent, or with local activities to introduce preferential programs.

(1) Initial cost $(\mathrm{NT} \$)=$ Light electric motorcycles $(100)+$ original battery $(50$ groups)

(2) Annual operating fee $(\mathrm{NT} \$)$ = Battery cost NT\$670,000/year+ energy cost NT\$0.075/km×8000km (estimated driving mileage per year) $\times 100$ vehicles/year + energy cost NT\$37,500/year + gear oil maintenance fee NT\$32,000/year + maintenance cost NT\$20,000/year.

(3) Annual manpower fee $(\mathrm{NT} \$)=5$ people $\times 12$ months/year $\times$ NT $\$ 22,000 /$ person month.

(4) Annual depreciation fee $(\mathrm{NT} \$)$ = electric motorcycles initial setting Cost 
$\times \frac{i \times(1+i) n}{(1+i) n-1}=$ electric motorcycles initial setting Cost $\times 0.055, \mathrm{i}=$ annual interest rate $(0.05), \mathrm{n}=$ depreciation period $(10$ years)

(5) Annual cost = Annual operating fee + annual manpower, maintenance fee, depreciation fee

Further, the purchase of electric motorcycles and general fuel motorcycles cost analysis and comparison; in the cost of electric motorcycle purchases, the local government in the purchase of light electric motorcycle subsidy NT\$15,000 /vehicle, the central government subsidy of NT\$10,000/vehicle, and if there is a replacement of the old two-stroke motorcycles to electric motorcycles, Taiwan EPA will subsidize NT\$3,000. Thus reducing the cost of electric motorcycle purchase. And in energy costs, regular maintenance costs, fuel tax and the cost of the purchase of batteries, three years as the benchmark estimate, the total cost of electric motorcycles is NT\$1,725, the general fuel motorcycles for NT\$30,750; to five years as the benchmark, the total cost of electric motorcycle is NT\$27,875, the general fuel motorcycle is NT\$48,700, 10 years as the benchmark estimate, the cumulative cost of motor vehicles is NT\$55,750, the general fuel motorcycles for NT\$98,000. The cumulative expenditure statistics are detailed as shown in Table 8.

Table 8. Cumulative expenditure of electric motorcycle and general fuel motorcycle

\begin{tabular}{|c|c|c|c|}
\hline \multicolumn{2}{|r|}{ Vehicle types } & $\begin{array}{l}\text { Light electric } \\
\text { motorcycle }\end{array}$ & Light motorcycle \\
\hline \multicolumn{2}{|c|}{ Cost of purchase (NT\$) } & $40,000 \sim 50,000$ & $50,000 \sim 60,000$ \\
\hline \multirow{4}{*}{$\begin{array}{l}\text { Three-year } \\
\text { accrued } \\
\text { expenditure }\end{array}$} & Energy costs ${ }^{(1)}(\mathrm{NT} \$)$ & 1,125 & 24,000 \\
\hline & $\begin{array}{l}\text { Regular maintenance } \\
\text { costs (2) (3) (NT\$) }\end{array}$ & 600 & 4,500 \\
\hline & Fuel tax ${ }^{(4)}(\mathrm{NT} \$)$ & 0 & 600 \\
\hline & Subtotal (NT\$) & 1,725 & 30,750 \\
\hline \multirow{5}{*}{$\begin{array}{l}\text { Five-year accrued } \\
\text { expenditure }\end{array}$} & Energy costs ${ }^{(1)}(\mathrm{NT} \$)$ & 1,875 & 40,000 \\
\hline & $\begin{array}{l}\text { Regular maintenance } \\
\text { costs }(2)(3)(\mathrm{NT} \$)\end{array}$ & 1,000 & 7,500 \\
\hline & Fuel tax ${ }^{(4)}(\mathrm{NT} \$)$ & -- & 1,200 \\
\hline & Battery cost ${ }^{(5)}$ (NT\$) & 25,000 & -- \\
\hline & Subtotal (NT\$) & 27,875 & 48,700 \\
\hline Ten-year accrued & Energy costs ${ }^{(1)}(\mathrm{NT} \$)$ & 3,750 & 80,000 \\
\hline
\end{tabular}




$\begin{array}{llll}\text { expenditure } & \begin{array}{l}\text { Regular maintenance } \\ \text { costs (2) (3) (NT\$) }\end{array} & 2,000 & 15,000 \\ & \begin{array}{l}\text { Fuel tax (4) (NT\$) } \\ \text { Battery cost }{ }^{(5)} \text { (NT\$) }\end{array} & -- & 3,000 \\ & 50,000 & -- \\ \text { Subtotal (NT\$) } & 55,750 & 98,000\end{array}$

(1) Energy cost and regular maintenance cost calculation method, the average day mileage per person is $13.6 \mathrm{~km}$, 3 years 15,000 kilometers, 5 years 25,000 kilometers, 10 years 50,000 kilometers calculation.

(Fuel oil consumption: $20 \mathrm{~km} / \mathrm{L}$, reference oil price of NT\$32/L; electric motorcycle energy consumption: $40 \mathrm{~km} / \mathrm{h}$, reference electric motorcycle price is NT\$3/kWh).

(2) Regular maintenance fee on oil (NT\$200) per 1,000 km/times, gear oil (NT\$80) per 2,000 $\mathrm{km} /$ times, air filter (NT\$300) per 5,000 km/times.

(3) Regular maintenance of motor vehicles only needs to replace the gear oil.

(4) Fuel tax is paid once per two years.

(5) The battery warranty period is 3 years, and the battery replacement frequency is changed per 4 years.

\section{Conclusions and Suggestion}

\subsection{Conclusions}

In this paper, the potential of electric motorcycles on the island is studied by means of investigation. As in many fast-growing cities in Asia, Latin America and Africa [18], the ownership and use of motorcycles have increased rapidly over the past two decades. Motorcycles offer inexpensive, relatively safe, easy point-to-point travel and control of transportation systems. However, they also reduce the quality of the urban environment and cause massive and harmful local pollution. Electric motorcycles can be explained by reducing one of the most damaging effects of motorcycles.

(1) Pre-matching inquiry

To complete the Zero Carbon Island target, to promote the operation of 100 electric motorcycles and battery demonstration, problems such as setting up the charging standard of motor car leasing, local industry rebound, incomplete vehicle certification and audit system, shipping vehicle charging standard and operation site, etc., so as to promote green transport.

Tourism satisfaction lies in transport facilitation and economic considerations, in order to enable people to jointly respond to carbon reduction action, the government set an incentive to rent charges, but also provide overnight island passengers, free rental 24-hour electric motorcycle.

Economic orientation, in order to increase the use of tourists, in addition to 
businesses set up battery exchange stations, prompting visitors to exchange batteries, and the introduction of "Carbon coupon", into the commodity consumption.

(2) Operating conditions

During the operation, the amount of electric motorcycle lease is 15,551 times, the total mileage of motor vehicle is $284,404 \mathrm{~km}$, the number of battery exchange is 622 times, the lease income is about NT\$900,000.

In addition to January, February for the trial operation during the period of the lease fee has less income, the average monthly income between March to December is about NT $\$ 80,000$. Carbon coupon issued a total of 14,218 , there is a use and exchange of 13,918 , the utilization rate of $97 \%$.

\subsection{Suggestion}

(1) To shoot marketing ads or short films to market island attractions to attract people's interest in Low-carbon Islands. In addition, it can be used with electric motorcycle general education and travel in depth.

(2) Electric motorcycles can be used across the islands, and provide an off-site return of services, so that tourists have a convenient and preferential choice.

(3) Rental costs may be adjusted, or a different lease-hours scheme can be introduced to increase the fixed income. In addition, schemes suitable for local residents, such as monthly, annual and hire-purchase schemes, can be introduced.

(4) In order to achieve the target of the low carbon island, it is suggested that in addition to the continuous promotion of green energy transport, we should speed up the scrap speed of the two-stroke motorcycles, so that the pollution can be effectively reduced.

\section{References}

1. Acquaye, A.A.; Duffy, A.P. Input-output analysis of Irish construction sector greenhouse gas emissions. Build Environ. 2010, 45, 784-91. 
2. Chang, Y.; Ries, R. J.; Wang, Y. The embodied energy and environmental emissions of construction projects in china: an economic input-output LCA model. Energy Policy 2010, 38, 6597-603.

3. Inter-governmental Panel on Climate Change. IPCC Fifth Assessment Report, IPCC. Retrieved on 18 April 2014 from < http://ipcc.ch/report/ar5/>

4. Peters, G.P. From production-based to consumption-based national emission inventories. Ecol Econ. 2008, 65, 13-23.

5. Yeung, J.S.; Wong, Y.D.; Secadiningrat, J.R. Lane-harmonised passenger car equivalents for heterogeneous expressway traffic. Res. Part A: Policy Pract. 2015, 78 (August), 361-370. http://dx.doi.org/10.1016/j.tra.2015.06.001.

6. Fan, Henry S.L. Passenger car equivalents for vehicles on Singapore expressways. Transp. Res. Part A: Gen. 1990, 24 (5), 391-396. http://dx.doi.org/10.1016/0191-2607(90)90051-7.

7. Adnan, Muhammad. Passenger car equivalent factors in heterogenous traffic environment-are we using the right numbers? In: Procedia Engineering, Fourth International Symposium on Infrastructure Engineering in Developing Countries, IEDC 2013, vol. 77, pp. 106-113. http://dx.doi.org/10.1016/j.proeng.2014.07. 004.

8. Rongviriyapanich; Terdsak; Suppattrakul; Charong. Effects of motorcycles on traffic operations on arterial streets. J. Eastern Asia Soc. Transp. Stud. 2005, 6, 137-146. http://dx.doi.org/10.11175/easts.6.137.

9. Huang, S.K.; Kuo, L.; Chou, K.L. The impacts of government policies on green utilization diffusion and social benefits - A case study of electric motorcycles in Taiwan. Energy Policy 2018, 119, 473-486.

10. Newman, P. W. G.; Kenworthy, J.R. Gasoline Consumption and Cities: A Comparison of U.S. Cities with a Global Survey. J. Am. Plann. Assoc. 1989, 55(1), 24-37. https://doi.org/10.1080/01944368908975398

11. Litman, T. Evaluating Transportation Equity. World Transport Policy and Practice 2002, 8(2), 50-65.

12. Leung, A.; Burke, M.; Perl, A.; Cui, J. The peak oil and oil vulnerability discourse in urban transport policy: A comparative discourse analysis of Hong Kong and Brisbane. Transport Policy 2017. https://doi.org/10.1016/j.tranpol.2017.03.023

13. Gilbert, R.; Perl, A. Transport revolutions: moving people and freight without oil (Revised and updated. ed., 2. ed.). 2010, Gabriola Island, BC: New Society.

14. WHO. WHO I Global status report on road safety 2015. Retrieved from http://www.who.int/violence_injury_prevention/road_safety_status/2015/e $\mathrm{n} /$

15. OECD/IEA. Global EV Outlook 2017. Retrieved from https://www.iea.org/publications/freepublications/publication/GlobalEVOu tlook 2017.pdf

16. Schuitema, G.; Anable, J.; Skippon, S.; Kinnear, N. The role of instrumental, hedonic and symbolic attributes in the intention to adopt electric vehicles. 
Transp. Res. Part A: Policy Pract. 2013, 48, 39-49. https://doi.org/10.1016/j.tra.2012.10.004

17. Dargay, J.; Gately, D.; Sommer, M. Vehicle Ownership and Income Growth,Worldwide: 1960-2030. Energy J. 2007, 28(4), 143-170.

18. IMF. World Economic Outlook (April 2017) - Nominal GDP per capita. Retrieved September 15, 2017, from http://www.imf.org/external/datamapper/NGDPDPC@WEO

19. Law, T.H.; Hamid, H.; Goh, C.N. The motorcycle to passenger car ownership ratio and economic growth: A cross-country analysis. EI95 Manual For Designers.Pdf. 2015, 46, 122-128. https://doi.org/10.1016/j.jtrangeo.2015.06.007

20. Wen, C.-H.; Chiou, Y.-C.; Huang, W.-L. A dynamic analysis of motorcycle ownership and usage: A panel data modeling approach. Accident Anal. Prev. 2012, 49, 193-202. https://doi.org/10.1016/j.aap.2011.03.006

21. Del Duce, A. Life Cycle Assessment of conventional and electric bicycles. In Eurobike 2011 conference. Retrieved from http://www.eurobikeshow.com/ebwAssets/daten/rahmenprogramm/pdf/LifeCycleAssessment_ DelDuce_englisch.pdf

22. Hamzah, A.; Haworth, N. Powered two wheelers in a changing worldChallenges and opportunities. Accident Anal. Prev. 2012, 44(1), 12-18. https://doi.org/10.1016/j.aap.2010.10.031.

23. Van Elslande, P.; Elvik, R. Powered two-wheelers within the traffic system. Accident Anal. Prev. 2012, 49, 1-4. https://doi.org/10.1016/j.aap.2012.09.007

24. Hsu, T.-P.; Sadullah, A.F.M.; Dao, N.X. A comparison study on motorcycle traffic development in some Asian countries-case of Taiwan, Malaysia and Vietnam. The Eastern Asia Society for Transportation Studies (EASTS), Int.Cooperative Res. Activity. 2003, Retrieved from http://citeseerx.ist.psu.edu/viewdoc/download?doi=10.1.1.460.2229andrep=r ep1and type $=$ pdf

25. Salmela, S.; Varho, V. Consumers in the green electricity market in Finland. Energy Policy, 2006, 34 (18), 3669-3683.

26. Eurobarometer. Energy: Issues, options and technologies, science and society. A report produced by The European Opinion Research Group (EORG) for the Directorate-General for Research. 2003, Luxembourg.

27. Zarnikau, J. Consumer demand for 'green power' and energy efficiency. Energy Policy, 2003, 31(15), 1661-1672.

28. Gan, L.; Eskeland, G.S.; Kolshus, H.H. Green electricity market development: lessons from Europe and the US. Energy Policy 2007, 35(1), 144-155.

29. Roe, B.; Teislb, M.F.; Levyc, A.; Russell, M. US consumers' willingness to pay for green electricity. Energy Policy 2001, 29, 917-925.

30. Truffer, B.; Markard, J.; Wüstenhagen, R. Eco-labeling of electricity Strategies and tradeoffs in the definition of environmental standards. Energy Policy 2001, 29(11), 885-897.

31. Peattie, K. Green consumption: behavior and norms. Annu. Rev. Env. Resour. 2010, 35, 195-228.

32. Norberg-Bohn, V. Stimulating green technological innovation: an analysis of alternative policy mechanisms. Policy Sci. 1999, 32, 1338. 
33. Stevens, C. Linking sustainable consumption and production: the government role. Nat. Resour. Forum 2010, 34, 16-23.

34. Young, W.; Hwang, K.; McDonald, S.; Oates, C.J. Sustainable consumption: green consumer behavior when purchasing products. Sustain. Dev. 2010, 18, 20-31.

35. Tran, M. Technology-behavioural modelling of energy innovation diffusion in the UK. Appl. Energy 2012, 95, 1-11.

36. Tseng, M.L.; Chiu, S.F.; Tan, R.R.; Anna, B.S.M. Sustainable consumption and production for Asia: sustainability through green design and practice. J. Clean. Prod. 2013, 40, 1-5.

37. Lorek, S.; Spangenberg, J.H. Sustainable consumption within a sustainable economy-beyond green growth and green economies. J. Clean. Prod. 2014, 63, 33-44.

38. Frederiks, E.R.; Stenner, K.; Hobman, E.V. Household energy use: applying behavioural economics to understand consumer decision-making and behavior. Renew. Sust. Energ. Rev. 2015, 41, 1385-1394.

39. Testa, F.; Cosic, A.; Iraldo, F. Determining factors of curtailment and purchasing energy related behaviors. J. Clean. Prod. 2015, 1-10. http://dx.doi.org/10.1016/j.jclepro.2015.07.134.

40. Jones; Luke, R.; Cherry, Christopher R.; Vu, Tuan A.; Nguyen, Quang N. The effect of incentives and technology on the adoption of electric motorcycles: a stated choice experiment in Vietnam. Transp. Res. Part A: Policy Pract. 2013, 57 (November), 1-11. http://dx.doi.org/10.1016/j.tra.2013.09.003.

41. Chiu, Y.C.; Tzeng, G.H. The market acceptance of electric motorcycles in Taiwan experience through a stated preference analysis. Transp. Res. Part D 1999, 4 (2), 127-146.

42. Sperling, D.; Gordon, D. Two Billion Cars: Driving Toward Sustainability. 2009, Oxford University Press.

43. Guerra; Erick; Artavia; Lucia. Energy Production and the Potential for Electric Motorcycles in Solo and Central Java, Indonesia. Policy Digest. 2016, Kleinman Center for Energy Policy. $<$ http://kleinmanenergy.upenn.edu/policy-digests/energy-production-andpotential-electric-motorcycles-solo-and-central-java-indonesia>.

44. Beggs; Steven, D.; Cardell, N.S. Choice of smallest car by multi-vehicle households and the demand for electric vehicles. Transp. Res. Part A: Gen. 1980, 14 (5-6), 389-404. http://dx.doi.org/10.1016/0191-2607(80)90057-6.

45. Brownstone; David; Bunch; David S.; Train, Kenneth. Joint mixed logit models of stated and revealed preferences for alternative-fuel vehicles. Transp. Res. Part B: Methodol. 2000, 34 (5), 315-338. http://dx.doi.org/10.1016/S0191-2615(99)00031-4.

46. Brownstone; David; Train; Kenneth. Forecasting new product penetration with flexible substitution patterns. J. Econom. 1998, 89 (1-2), 109-129. http://dx.doi.org/10.1016/S0304-4076(98)00057-8.

47. Calfee; John, E. Special issue economic models of automobile demand estimating the demand for electric automobiles using fully disaggregated 
probabilistic choice analysis. Res. Part B: Methodol. 1985, 19 (4), 287-301. http://dx.doi.org/10.1016/0191-2615(85)90037-2.

48. Daziano; Ricardo A. Conditional-logit Bayes estimators for consumer valuation of electric vehicle driving range. Resour. Energy Econ. 2013, 35 (3), 429-450. http://dx.doi.org/10.1016/j.reseneeco.2013.05.001.

49. Cherry; Christopher; Cervero; Robert. Use characteristics and mode choice behavior of electric bike users in China. Transp. Policy 2007, 14 (3), 247-257. http://dx.doi.org/10.1016/j.tranpol.2007.02.005. 
